\title{
Täyttä päivää työttömänä
}

\section{Työn ja ei-työn rajalla}

\author{
Uuden työn myötä raja työn ja ei-työn välillä \\ hämärtyy. Etenkin prekaarissa työmarkkina- \\ asemassa olevien on käytettävä yhä enemmän \\ aikaa sellaisen työn tekemiseen, jonka tavoitteena \\ on työn saaminen tai säilyttäminen.
}

$\boldsymbol{y}$ ON ESITETTY, ETTÄ vuoteen 2050 mennessä ihmiset työllistyvät osaamisensa perusteella ja erilaisia suhdeverkostoja hyväksi käyttäen suuriin tai pieniin projekteihin. Suuria organisaatioita ei enää ole, vaan niiden sijaan on alati muuttuvia ja suhteellisen itsenäisten projektien muodostamia verkostoja. Useimmilla työelämään osallistuvilla ei ole enää vakinaisia työsuhteita, täsmällisesti määriteltyjä työaikoja tai kiinteitä työnantajan osoittamia työpisteitä. Sen sijaan työt tehdään kulloinkin tarkoituksenmukaisissa paikoissa sopivalla hetkellä. Palkka maksetaan suoritteista eikä nykyiseen tapaan ajan perusteella. (Kasvio 2014, 226.)

Jo nyt työ pirstaloituu monin tavoin, ja useiden työ koostuu erilaisten ansaintamuotojen, projektien ja pätkien yhdistämisestä. Parhaiten tämä käy ilmi niiden freelancereiden kohdalla, jotka työskentelevät sekä yrittäjinä että palkkatyössä ja kokoavat toimeentulonsa monista eri lähteistä. Samaan aikaan näyttää siltä, että usein sekä työlainsäädäntö että työelämän tutkimus erottelevat edelleen työntekijät ja yrittäjät toisistaan erillisiksi ryhmiksi tunnistamatta tätä työn teettämisen tapojen ja työnteon muodollisen organisoinnin muutosta.

Artikkeli sijoittuu uuden työn tekemisen muotojen mukanaan tuomaan kehykseen, jossa työelämä haurastuu ja muuttuu monin eri tavoin yhä epävarmemmaksi. Tätä haurastumista ja yhteiskunnallisten asemien menettämistä kutsutaan prekarisoitumiseksi (Jokinen 2013; Silvasti ym. 2014; Åkerblad 2014). Prekarisoitumisen välttämiseksi tai vähentämiseksi monet työntekijät ovat alkaneet tehdä yhä enemmän 
ei-työtä, joka kuitenkin tähtää työnteon edellytysten parantamiseen.

Analysoin, millä tavoin uuden työn myötä prekaarissa työmarkkina-asemassa olevien työntekijöiden työ jäsentyy ja limittyy ei-työn kanssa. Lisäksi pohdin, millaisia seurauksia työelämän haurastumisella on työntekijöiden muuhun elämään. Tarkastelen uutta työtä ja sen mukanaan tuomia muutoksia erityisesti feministisen työelämän tutkimuksen käsitteistön ja keskustelujen pohjalta, koska ne tarjoavat artikkelin kysymyksenasettelun kannalta tarpeellista tarttumapintaa työelämän laitamien ja ei-työn tarkasteluun. Siihen, miten uuden työn jaot ja niiden seuraukset jakaantuvat naisten ja miesten kesken, en voi ottaa kantaa tämän artikkelin aineiston perusteella. Artikkelin empiirisenä materiaalina käytän 21 puolistrukturoitua haastattelua.

Työmarkkinat osoittavat vahvoja merkkejä haurastumisesta (esim. Jokinen 2013; Silvasti ym. 2014; Åkerblad 2014), joskaan tämä kehityssuunta ei juurikaan näy tilastoaineistoihin, kuten työolotutkimukseen perustuvissa analyyseissä. Onkin esitetty epäilys, jonka mukaan työelämän epävarmuutta ja prekaarin palkkatyön yleisyyttä liioitellaan (Pyöriä \& Ojala 2016). On myös todettu, että väite työmarkkinoiden yleisestä epävakaistumisesta on väärinkäsitys. Sen sijaan työmarkkinat ovat 2000-luvulla jakautuneet kahtia, vakaisiin ja epävakaisiin työmarkkinoihin. Osa työvoimasta, erityisesti ikääntyneet, vähän koulutetut ja työttömät ovat ajautuneet yhä lyheneviin työsuhteisiin. Lisäksi nuoret, opiskelijat ja naiset kohtaavat alati epävakaistuneet työmarkkinat. (Soininen 2015.) Esimerkiksi saman korkeakoulututkinnon suorittaneista miehet sijoittuvat naisia nopeammin työelämään, heillä on naisia todennäköisemmin kokoaikainen työ, ja he ovat korkeammissa asemissa sekä koulutustaan vastaavissa tehtävissä useammin kuin naiset (VuorinenLampila 2016). Näyttää siis siltä, että elämänvaiheella, koulutuksella ja sukupuolella on keskeinen merkitys sen kannalta, millaiset työmarkkinat työntekijä kohtaa.

\section{UUSI TYÖ}

Uusi työ on käsite, jonka alle on koottu joukko 2000-luvun työelämän ja työn tekemisen piirteitä. Näitä uuden työn piirteitä ovat työn subjektivoitumi- nen, tietoistuminen, affektisoituminen ja prekarisoituminen. Työ kiinnittyy entistä enemmän ja tiukemmin tekijänsä persoonaan, ulkonäköön ja tunteisiin sekä niiden esittämiseen. Samaan aikaan työ pirstoutuu osa-aikaisuuksiksi, pätkittyy ja muuttuu tekijänsä henkilökohtaisiksi projekteiksi niin, ettei rajaa työn ja ei-työn välille ole aina mahdollista vetää. Lisäksi uusi työ on joustavaa ja liikkuvaa sekä paikaltaan että sisällöltään. Se sijoittuu uusliberalistiseen kapitalismiin, jota on vastaavasti alettu kutsua uudeksi taloudeksi. (du Gay \& Morgan 2013; Jokinen 2005; Julkunen 2008; Koivunen 2013.)

Uusi työ nostaa esiin sukupuolen erityisesti työn feminisoitumisen käsitteellistyksen avulla (Julkunen 2008; Morini 2007; Vähämäki 2011). Työn feminisoituminen viittaa ensinnäkin siihen, että perinteisesti miesenemmistöisillä aloilla ja ammateissa on määrällisesti koko ajan enemmän naisia. Lisäksi kaikkien työsuhteiden niin kutsuttu epätyypillisyys eli esimerkiksi osa- ja määräaikaisuus on lisääntynyt, kun aiemmin epätyypillisissä työsuhteissa työskenteli enimmäkseen naisia. Kolmanneksi työn feminisoituminen viittaa siihen laadulliseen muutokseen, jonka seurauksena uusi työ muistuttaa sekä sisällöltään että ehdoiltaan työtä, joka on ollut naisille tyypillistä. Uudessa työssä työntekijöiltä edellytetään jatkuvaa valmiutta, kommunikaatiokykyä, joustavuutta ja palvelualttiutta. (Adkins \& Jokinen 2008; Jokinen 2005.)

Tämän seurauksena työ ja vapaa-aika eivät ole enää selkeästi erotettavissa toisistaan, kun työ alkaa muistuttaa yhä enemmän kodin ja perheen piirissä tehtävää, rajatonta ja päättymätöntä hoivaa ja huolenpitoa. Niinpä työ feminisoitumisen sijaan puhutaan myös työelämän käytäntöjen kotitöistymisestä (Jokinen 2005, 83), mikä jo käsitteenä viittaa työn ja ei-työn rajan hämärtymiseen.

Työn feminisoituminen vaikuttaa sekä miehiin että naisiin ja siksi sen voi ajatella ylittävän sukupuolten välisiä jakoja. Vaihtoehtoisesti työn feminisoitumista itsessään voi pitää sukupuolistavana käytäntönä, joka järjestää uudelleen sekä laajoja, sukupuoleen liittyviä yhteiskunnan tason toimia että arkisia sukupuolistavia käytäntöjä työpaikoilla. Yhtäältä naistapaisen työn lisääntyminen ja tällaisten taitojen vaatiminen monessa työssä luovat kysyntää naisille yleisesti tutulle työtaval- 
le ja työn käytännöille. Toisaalta on esitetty, että naisilta uuden työn taitoja odotetaan automaattisesti, eikä näistä "luonnollisista" kyvyistä siten palkita naisia. Sen sijaan miehet saavat konkreettista arvostusta, kun he omaksuvat naistapaisuutta (Adkins \& Jokinen 2008).

Esimerkiksi hymyilevät, ystävälliset ja asiakaspalveluhenkiset miestyöntekijät voivat menestyä erilaisissa palveluammateissa sekä asiakkaiden että työnantajan silmissä erityisen hyvin ja saada bonuspalkkioita, provisioita ja juomarahaa runsaammin kuin naistyöntekijät. On kuitenkin huomattava, että kaikki miehetkään eivät osaa yhtä helposti omaksua uuden talouden palvelutyöntekijän ulkoista olemusta ja toimintatapoja.

Samaan aikaan uusi työ perustuu ajatukselle, jonka mukaan työntekijän normi on edelleen mies. Huolimatta kaikesta naisten arvoa käsittelevästä puheesta, naisten panoksen uuden talouden työlle on esitetty pienenevän, koska naisilla ei ole näkyvää paikkaa uuden talouden kannalta oleellisilla areenoilla. Toinen keskeinen syy naisten panoksen pienenemiseen on se, että usein uuden talouden työssä menestyminen edellyttä pitkiä työpäiviä ja raskasta matkustamista tahtiin, joka jättää muulle elämälle ja perheelle aikaa vain rajoitetusti. (Adkins 2008, 188; Trift 2000; 2005, 121.) Samalla uuden talouden ideologian mukaisesti sukupuolistuneiden käytäntöjen, kuten sukupuolistuneen työnjaon merkitys työelämässä kielletään. Tällöin katsotaan, että yksilö on itse vastuussa pärjäämisestään. Hän kykenee menestymään työmarkkinoilla sukupuolestaan huolimatta tai sitä tilanteen mukaan sopivalla tavalla hyödyntäen.

Uuden työn myötä työn tekemisen ja teettämisen käytännöt ovat muuttuneet, mutta niin on myös työn sääntely. Työelämän kollektiiviset sopimukset ja suoja purkautuvat ja korvautuvat yksilöllisillä sopimuksilla, henkilökohtaisilla neuvotteluilla ja sääntelemättömyydellä (Suoranta \& Anttila 2010). Yksi esimerkki on kannustaminen yrittäjyyteen, jolloin työntekijän suhteellisen turvattu asema vaihtuu itsensä työllistävän freelancer-yrittäjän huomattavasti suojattomampaan asemaan. Tällöin kyse saattaa olla jopa vastentahtoisesta tai näennäisestä yrittäjyydestä, jota kutsutaan palkkatyön jälkeiseksi työksi (Julkunen 2008; Koivunen \& Ojala 2015; Pärnäinen \& Sutela 2014).
Toisaalta uusi osuuskuntalaki on mahdollistanut osuuskuntien laajemman perustamisen ja toiminnan, ja samalla osuuskunnan jäsenten "kevytyrittäjyyden". Näin siitä huolimatta, että esimerkiksi osuuskunnassa työskentelevien henkilöiden työttömyysturvaa harkitaan tapauskohtaisesti. On mahdollista, että esimerkiksi harrastusohjaaja voi osuuskunnan kautta työskennellä yrittäjämäisesti eri harrastuspaikoissa menettämättä samalla palkkatyöläisen suojaa, jos hänen kevytyrittäjyytensä ei katsota estävän tätä.

Uusi työ muokkaa myös työn ja muun elämän yhteen sovittamisen tapoja sekä muuta elämää laajemminkin. Nämä tavat seuraavat usein sukupuolen ja perhetilanteen mukaisia jakoja, eivätkä siten ole kaikilla työntekijöillä symmetrisiä tai samanlaisia. Äidit ja isät tekevät eri asioita, eivätkä äidin ja isän ideaalit ole samanlaisia (Jokinen 2005, 129). Lisa Adkins $(2012,624)$ on todennut, että äitiys on muutoksessa uuden työn ja talouden myötä niin, että hyvä äitiys tarkoittaa työntekijyyttä työmarkkinoilla pikemminkin kuin kotitöiden tekemistä ja epäitsekästä hoivatyötä kodin ja perheen piirissä. Tässä suhteessa hyvä äitiys alkaa muistuttaa hyvää isyyttä, vaikka samalla sukupuolten väliset jaot myös vanhemmuuden suhteen säilyvät.

\section{AINEISTO JA MENETELMÄT}

Tutkimuksen empiirinen aineisto koostuu 21 haastattelusta (20 naista ja yksi mies), jotka on toteutettu joko kasvokkain tai puhelimella keväällä 2015. Haastateltujen ikähaarukka on 34-55 vuotta. Aineisto on tuotettu Flexlife-tutkimushankkeessa (Suomen Akatemia, nro. 277376). Haastatellut ovat valikoituneet tutkimukseen niin, että he ovat osallistuneet erääseen aiempaan tutkimushankkeeseen, jolloin heiltä on tiedusteltu heidän mahdollista halukkuuttaan osallistua jatkossa myös haastattelututkimukseen. Halukkuutensa ilmaisseista henkilöistä tähän tutkimukseen ovat valikoituneet ne, jotka on yhteystietojen avulla tavoitettu ja joilla on ollut mahdollisuus haastatteluun.

Tutkimushaastattelut ovat puolistrukturoituja, ja niiden kesto vaihtelee noin puolesta tunnista reiluun tuntiin. Haastattelukysymyksissä on keskitytty erilaisiin ajankäyttöön ja kiireeseen liittyviin aiheisiin, kuten työaikaan ja siihen liittyviin neuvottelui- 
hin, vaikutusmahdollisuuksiin, aikasuunnitteluun ja ajankäytön hallintaan; kiireeseen työssä ja työn ulkopuolella; arjen ajankäyttöön, kotitöiden jakamiseen ja aikaneuvotteluihin perheen kesken sekä teknologian käyttöön ajanhallinnassa. Vaikka haastatteluteemat keskittyvät ajankäyttöön ja kiireeseen, tarjoaa aineisto rikkaan ja monipuolisen materiaalin, josta voi lukea monenlaisia tietotyön ja asiantuntijatyön kysymyksiin keskittyviä käytäntöjä ja kokemuksia.

Haastateltuja yhdistää se, että he kuuluvat samaan ammattiliittoon ja he ovat osallistuneet aiempaan tutkimukseen. Lisäksi kaikki haastatelluista, yhtä poikkeusta lukuun ottamatta, työskentelevät erilaisissa tietotyön ammateissa, suurin osa hyvinkin itsenäisissä asiantuntijapositioissa. Tietotyötä määrittävät tietotekniikan käyttö, työn tekijän suhteellisen korkea korkea koulutus ja suuri itsenäisyys (Pyöriä 2006). Haastatelluista 15 työskentelee toistaiseksi voimassa olevassa työ- tai virkasuhteessa, heistä kolme osa-aikaisesti. Viisi haastateltua työskentelee määräaikaisessa, mutta suhteellisen pitkässä työsuhteessa.

Poikkeuksen aineistoon muodostaa yksi haastateltu nainen, joka on haastatteluhetkellä työtön asiantuntijatehtävästään, sillä hänet on irtisanottu, kun yritys on lopettanut toimintansa. Haastateltavalla on toinen ammatti harrastustoiminnan ohjaajana, ja tätä ammattiaan hän harjoittaa työttömänä ollessaan. Aineiston analyysissä keskityn tähän haastatteluun muita enemmän. Myös kaikki artikkelissa esitetyt haastattelusitaatit ovat harrastustoiminnan ohjaajan sitaatteja. Tällainen analyysin tapa tarjoaa mahdollisuuden keskittyä työn tekemiseen, työn rajojen sekä työn ja muun elämän yhteensovittamiseen liittyviin kysymyksiin hänen prekaarin työmarkkinatilanteensa näkökulmasta.

Olen käyttänyt teoriaohjaavaan sisällönanalyysiin (Krippendorff 2004; Saari 2014; Tuomi \& Sarajärvi 2009) pohjautuva menetelmää, jossa olen keskittynyt uuden työn ja sukupuolen kannalta keskeisiin teemoihin ja kysymyksiin. Teoriaohjaavassa sisällönanalyysissä teoria toimii analyysin tekemisen apuna niin, että se suuntaa analyysiä, mutta lopullinen analyysin tapa rakentuu vuoropuhelussa aineiston ja uuden työn käsitteellistysten sekä aiempien tutkimusten kanssa (Saari 2014, 54; Tuomi \& Sarajärvi 2009, 96-97).
Vaikka olen analyysissä keskittynyt erityisesti yhteen, harrastustoiminnan ohjaajan haastatteluun, olen samalla analysoinut koko haastatteluaineistoa. Konkreettisesti olen edennyt niin, että olen lähilukenut valmiiksi litteroitua aineistoa ja teemoitellut sen tutkimuskysymysten kannalta keskeisten teemojen avulla. Niitä ovat palkkatyö, palkaton työ, opiskelu sekä työn ja muun elämän yhteensovittaminen, työn tekemisen paikat, ajat ja välitilat erityisesti sukupuolen näkökulmasta. Näitä teemoja olen tarkastellut rinnakkain sekä uuden työn että sukupuolen teoretisointien, käsitteellistysten ja empiiristen tutkimusten kanssa. Olen suhteuttanut harrastustoiminnan ohjaajan haastattelussaan esittämiä työn ja muun elämän erityispiirteitä sekä keskeisiä teemoja koko haastatteluaineiston muodostamaan kokonaisuuteen. Näin tehdessäni olen keskittynyt sekä eroihin että samankaltaisuuksiin haastattelujen välillä.

\section{TYÖN JA EI-TYÖN RAJOILLA}

Harrastustoiminnan ohjaaja on alle 50-vuotias nainen, jolla on aviomies ja kaksi alakouluikäistä lasta. He asuvat suuressa suomalaisessa kaupungissa, jossa harrastavien ihmisten suuri määrä mahdollistaa harrastustoiminnan ammattimaisen ja laajamittaisen ohjaamisen. Harrastustoiminnan ohjaajaa voi kutsua siinä mielessä prekaariksi työntekijäksi, että hän työskentelee freelancerina eli tekee osa-aikaisia, määräaikaisia töitä useille eri työnantajille.

Haastatteluhetkellä harrastustoiminnan ohjaaja oli ollut työttömänä noin kaksi vuotta. Sitä ennen hän oli työskennellyt asiantuntijatehtävissä pienessä yrityksessä, josta hänet oli lomautettu tuotannollistaloudellisista syistä. Tämän jälkeen yritys lakkasi ohjaajan sanojen mukaan olemasta, mutta hän ei kerro tarkemmin miten ja miksi. "Minullekin monesta paikasta työtä tarjottiin, mutta ne on kaikki bonuspalkattuja töitä", hän toteaa. Toisin sanoen hänelle tarjottiin töitä vain provisiopalkalla, kuten hän myöhemmin tarkentaa, mutta hän ei halunnut vastaanottaa tällaista työtä ja tehdä pitkiä työpäiviä ilman varmuutta siitä, saako hän työpanoksensa vastineeksi rahallista korvausta. Sen sijaan hän siirtyi työskentelemään toisessa ammatissaan harrastustoiminnan ohjaajana. 
Haastateltujen asiantuntijoiden joukossa on useita henkilöitä, joilla on pääasiallisen ammattinsa lisäksi muita ammatteja. Yleistäen voi sanoa, että asiantuntijatyönsä lisäksi he opettavat tai ohjaavat. Joillain opettaminen tai ohjaaminen liittyy heidän pääasialliseen ammattiinsa. Tällöin opettaminen näyttäytyy luontevana jatkumona heidän asiantuntijuudelleen. Sen sijaan joidenkin asiantuntijoiden toinen ammatti on jonkin tyystin muun kuin heidän asiantuntijuuteensa liittyvän asian opettamista. Tällöin opettaminen muodostaa vastapainon heidän asiantuntijatyölleen.

Harrastustoiminnan ohjaaminen on työtä, jonka tekemisellä on omat reunaehtonsa. Niistä merkittävin on ajan rajallisuus. Haastateltu ohjaaja työskentelee useiden eri työnantajien palveluksessa eri paikoissa. Siksi siirtymät paikasta toiseen rytmittävät mutta myös rajoittavat hänen työpäiväänsä keskeisellä tavalla.

"Nyt esimerkiks mulla tässä kevään aikana nää tiistait ja keskiviikot on ollu erittäin hyviä työpäiviä, mikä tarkoittaa sitä, että mun ensimmäinen tunti alkaa kello yhdeksältä, ja mun viimeinen tunti päättyy siinä puoli neljältä, ja mulla on peräti viisi tuntia sellaista, mistä mulle maksetaan palkkaa siinä välissä. Nää tiistai ja keskiviikko on sellaisia, jossa mulla on ihanteelliset siirtymät, eli mulla on alle 10 kilometrin siirtymä työpaikalle, ja on vaan yksi siirtymä työpäivän aikana, ja sitten paluu kotiin. Sellaiset nimenomaan huonommat työpäivät [nauraa] tai rikkonaisemmat, niin ne saattaa olla sitä, että mulla on keskustassa tunti aamulla seitsemältä tai puoli kahdeksalta, ja sit saattaa olla illan viimeinen tunti taas [keskustassa] sillä tavalla, että se loppuu esimerkiks vasta seitsemältä tai kahdeksalta."

Harrastustoiminnan ohjaajalle viisi tuntia palkallista työtä yhden kuusi-seitsemäntuntisen työpäivän aikana on hyvä työpäivä. Usein hänen työpäivänsä on tätä pidempiä siirtymien ja palkattoman työn takia, mikä näyttää olevan tavallista tämän tyyppisessä työssä (Koivunen \& Ojala 2015). Uuden työn tekeminen perustuu usein, etenkin miesten ja johtajien kohdalla, verkostoissa toimimiseen ja olemiseen joka paikassa yhtä aikaa tieto- ja viestintäteknologian avulla (Koivunen 2013, 25). Kuitenkaan harrastustoiminnan ohjaajan työ ei ole paikatonta siinä mielessä, että hänen on oltava harrastajien kanssa samassa paikassa tietyyn aikaan. Sikäli hänen työnsä muistuttaa perinteistä palvelutyötä.

Harrastustoiminnan ohjaajan työtehtävät sisältävät sekä palkallista työtä että myös työtä, josta hänelle ei makseta korvausta. Tällaista palkatta tehtävää työtä on esimerkiksi omien kurssien mainostaminen, raportointi, kurssitarjousten tekeminen sekä tuntien suunnittelu ja valmistelu, jota hän tekee kotonaan silloin, kun hän palkallisen työn aikatauluiltaan ehtii, eli yleensä aamuisin, iltaisin ja viikonloppuisin. Hän voi toimia näin, koska työttömyys ja sen mukanaan tuoma tuntitöiden tekeminen on temporaalinen tilanne, jonka ei ole tarkoitus jatkua pitkään (Adkins 2012). Tilanteen pitkittyessä toimintatapaa olisi todennäköisesti pakko muuttaa jollakin tavalla. Yksi uuden työn piirre onkin, että prekaarissa asemassa työskentelevien on käytettävä paljon varsinaisen palkkatyön ulkopuolista aikaa ja vaivaa työn hankkimiseen. Tämä voi tarkoittaa esimerkiksi erilaisten suhteiden luomista ja ylläpitoa tai itsensä markkinoimiseen tähtääviä toimia.

Tällaisesta palkkatyön ulkopuolisesta panostuksesta huolimatta työntekijä ei voi olla varma oman työnsä pysyvyydestä ja jatkuvuudesta, kuten harrastustoiminnan ohjaaja tilannettaan kuvaa.

"Nyt mä oon tällä hetkellä virallisesti vielä työttömänä, koska nää on kaikki keikkatöitä, eli jokainen työrupeama pohjautuu siihen, että tuleeko riittävä mä̈rä asiakkaita paikalle. Jos ei tule, niin tunnit loppuu kahden viikon irtisanomisajalla täälä julkisella puolella ja sitten yksityissektorilla ne loppuu ihan saman tien, siellä ei edes tällaisia virallisia irtisanomisaikoja käytännössä noudateta."

Uuden työn keskeisiin piirteisiin kuuluu työntekijöiden kollektiivisten suojien purkautuminen (Julkunen 2008; Suoranta \& Anttila 2010). Suojia voidaan purkaa tietoisesti esimerkiksi muuttamalla työlainsäädäntöä, tai harrastustoiminnan ohjaajan yllä esittämällä tavalla, jolloin työlainsäädäntöä tai työehtosopimuksia ei enää noudateta. Kollektiivisten suojien noudattamatta jättämistä voidaan perustella sillä, että ei tunneta lainsäädäntöä tai sopimuksia, tai sitten niitä ei haluta noudattaa joko taloudellisista tai muista syistä. (Koivunen \& Ojala 2015.) 


\section{OPISKELU INVESTOINTINA TULEVAISUUTEEN}

Vaikka harrastustoiminnan ohjaajan päivät täyttyvät palkallisesta ja palkattomasta työstä sekä siirtymistä työn tekemisen paikkojen välillä, ehtii haastateltu tämän lisäksi opiskella.

"Sit ihanne tässä nyt on ollu just, että pyrkis siihen, että olis muutama täys työpäivä ja sitten muina päivinä pystyis sitten, kun mulla on pikkasen opintoja vielä mitä mä haluun loppuun. Että ois pystynyt erottamaan sillä tavalla, että olis ne harrastusryhmätyöpäivät ja olis nää opintopäivät. Mutta tähän asti se on ollu kyllä enemmän sitä, että tenttikirjan on kulkenut mukana ohjaustuntien välissä ja hyvin luovissa paikoissa olen lukenut tai kirjoittanut jotain esseetä tai muuta. Ne tunnit mistä maksetaan, niin ne on ne, mitkä on rytmittänyt sitä päivää ja muuta työtä tehdään hyvin luovasti erilaisissa lyhyissäkin sloteissa."

Opiskelu rinnastuu palkattomaan työhön siinä mielessä, että hän tekee sitä palkallisen työn lomassa, niinä hetkinä ja sellaisissa paikoissa kuin palkkatyö antaa myöten. Toisin sanoen opiskelulle varattu aika ja paikka ovat riippuvaisia palkkatyöstä. On sanottu, että prekarisoitumisen myötä koulutuksen paikka muuttuu. Kun koulutus aiemmin vahvisti, varusti ja suojasi yksilöitä, tekee se nyttemmin ihmisistä epävarmoja itseensä investoijia (Jokinen 2013, 6). Tällöin koulutus ei välttämättä enää takaa entiseen tapaan vakaata työmarkkina-asemaa ja tulokehitystä (Silvasti ym. 2014). Myös harrastustoiminnan ohjaajan haastattelusta opiskelun voi lukea olevan nimenomaan investointi tulevaisuuteen ja osoitus jatkuvasta halusta kehittää itseään ja osaamistaan. Siinä missä pirstaleinen työelämä edellyttää hyvää koulutustaustaa, työn henkilökohtaistuminen edellyttää oppimishalun ja -kyvyn osoittamista. Jatkuva kouluttautuminen tarjoaa helposti hahmotettavan väylän työmarkkina-aseman kohentamiseen, vaikka selvärajainen ja joustamaton koulutus ei kuitenkaan pysty vastaamaan uuden työn monimutkaistuviin vaatimuksiin (Åkerblad 2014, 35).

Suomalaiset uskovat sitkeästi koulutukseen ja koulutus nähdään edelleen keinona itsenäisyyteen ja parempaan elämään. Sitä se monille onkin, mutta ei automaattisesti kaikille. Koulutuksen on sanottu käänty- neen epävarmuutta lisääväksi tekniikaksi, jonka avulla ihmisiä aktivoidaan, pidetään hereillä ja varuillaan. (Silvennoinen \& Klas 1996; Vähämäki 2011, 181.) Koulutukselliset saavutukset ovat erilainen resurssi naisille ja miehille. Naiset tavoittelevat korkeaa koulutusta keskimäärin useammin kuin miehet, ja naiset myös tarvitsevat keskimäärin miehiä useammin korkeaa koulutusta menestyäkseen sukupuolen mukaan eriytyneillä työmarkkinoilla. (Lahelma 2014.)

\section{KOTI, PERHE JA PUOLISO}

Siinä missä koko aineiston asiantuntijatehtävissä työskentelevistä naisista monet tekevät lyhennettyä työaikaa ja yrittävät rajata niin ylitöiden tekemistä kuin töiden tekemistä kotonakin, harrastustoiminnan ohjaaja toivoo saavansa vakituisten viikkotuntien muodostamaan palapeliin lisää palkallisia työtunteja, keikkatunteja. Hän sanoo:

"Mä oon esimerkiks asettanut itelleni semmoisen tavoitteen, (...) että mä teen niin paljon päiväajan tunteja mitä mä saan, eli kaikki sellaiset tunnit milloin mä pystyn menemään ohjaamaan niin, että mun lapset on koulussa tai tarhassa tai iltapäiväkerhossa."

Hän siis haluaa lisää palkallisia työtuntejaan, mutta vain niiltä osin, kuin tunnit sijoittuvat sellaiseen aikaan, joka ei ole pois hänen perheensä kanssa viettämästä ajasta.

Oletettavasti juuri prekaarin työmarkkina-asemansa takia harrastustoiminnan ohjaaja ei kuulu niihin työssään ahdistuneisiin, muutosta etsiviin elämänsä hidastajiin eli downshiftaajiin, jotka pyrkivät kovan työnteon hylkäämiseen, koska se ei enää tuotakaan onnea. Työelämässä, jossa paikoilleen jääminen on pahasta ja jossa yksilön valtteja ovat nopeus ja muutosvalmius, hidastajat asettuvat ikään kuin vastahankaan näiden vaatimusten kanssa. (Ikonen 2010, 43.) Kaikilla ei kuitenkaan ole varaa tai haluakaan tällaiseen hangoitteluun ja oravanpyörästä pakenemiseen, sillä joidenkin työssä ja tarkemmin sanottuna työtuntien määrässä on edelleen kyse rahasta ja toimeentulosta. Tulkitsen, että näin on suurelta osin myös harrastustoiminnan ohjaajan kohdalla.

Harrastustoiminnan ohjaaja haluaa kuitenkin ohjata enimmäkseen päiväaikaan kokoontuvia ryhmiä, ja 
tähän hänellä on myös käytännön mahdollisuus. Mikäli näin ei olisi, sijoittuisivat hänen ohjaamansa tunnit niin kutsutun normaalityöajan jälkeen, eli käytännössä iltoihin. Tällä olisi merkittävä vaikutus hänen työaikoihinsa ja samalla perhe-elämän käytäntöjen järjestämiseen.

Vaikka harrastustoiminnan ohjaajan palkallinen työ on ensisijaista palkattomaan työhön ja opiskeluun nähden, ei palkkatyö kuitenkaan priorisoidu muun elämän edelle. Hän haluaa ottaa vastuuta myös perheen arkisista käytännöistä ja hakea lapset koulusta tiettyinä päivinä viikossa. Sama perheen ensisijaisuus työhön nähden toistuu koko haastatteluaineistossa. Työ halutaan rajata pois perheen yhteisestä ajasta, ja etenkin lasten kanssa vietetystä ajasta.

On paljon mahdollista, että äitiys on Adkinsin (2012) esittämälllä tavalla muutoksessa uuden työn myötä, ja että harrastustoiminnan ohjaaja työskentelee freelancerina tuntiperustaisissa työsuhteissa "toimiakseen oikein" lastensa hyväksi, kuten Adkins $(2012,624)$ asian esittää. Kuitenkin lasten elämään osallistuminen ja arjen eläminen heidän ehdoillaan näyttää tämän aineiston valossa olevan edelleen tärkeää perheellisille, palkkatyötä tekeville naisille.

Naisten tekemällä palkkatyöllä on pitkät perinteet Suomessa. Se ei kuitenkaan tarkoita, että naisten ja miesten työtä pidettäisiin samanarvoisena yhteiskunnassa tai edes perheissä. Myös harrastustoiminnan ohjaaja on havainnut perheen sisäisen hierarkian palkkatyön arvostuksen suhteen.

"Meiän avioliiton alkuaikoina, yhteiselon alkuaikoina aika paljon selvemmin oli niin, tai mä koin niin, että mieheni piti hänen työtään ja hänen menojaan tärkeämpänä ja tää mun harrastustoiminnan ohjaus oli enemmänkin, hän vertasi sitä omiin harrastuksiinsa. Semmoinen asetelma oli kyllä alkuvaiheessa. Mut sit kun mä olin sen pari vuotta [asiantuntijatyössä], niin silloinkin ehkä tietyllä tavalla meidän asemaero siinä, missä asemassa kumpikin oli omissa työyhteisöissään, niin ehkä vähän koin, että aiheutti samaa. Mutta sitten mä oon varmaan itse ruvennut asennoitumaan omaan työhöni ja arvostamaan itse omaa työtäni ja tätä että freelancerinakin voi olla arvokas siinä omassa työssään."
Harrastustoiminnan ohjaaja kuvaa, kuinka hänen työnsä on vertautunut hänen miehensä harrastukseen. Oletettavasti hän onkin päätynyt toiseen ammattiinsa oman harrastuksensa kautta. Hänen harrastuksestaan on tullut ammatti ja työ, jolla hän voi osallistua perheensä elättämiseen ainakin hetkellisesti.

Naissukupuoli on riskitekijä työn prekarisoitumisessa (Soininen 2015), ja myös työn feminisoituminen koskee miesten ammatteja sekä miesten tekemiä töitä. Tästä on häivähdys havaittavissa harrastustoiminnan ohjaajan haastattelussa. Toisin sanoen myös harrastustoiminnan ohjaajan puoliso on joutunut huomaamaan työn haurastumisen.

"Tässä myös mieheni työkuviot muuttuivat tässä vuoden sisällä että ehkä hänkin huomasi että työuralla eteneminen, niin ei se aina ole tässä markkinatilanteessa ehkä sit ihan kuitenkaan sellaista... suoraviivaista ja itsestään selvää. Tässä markkinatilanteessa työuralla voi tulla erilaisia vaiheita ja erilaisia joustovaatimuksia ja erilaisia tiettyjä."

Harrastustoiminnan ohjaaja katsoo työn haurastumisen olevan seikka, joka kytkeytyy nykyiseen markkinatilanteeseen (myös Pyöriä \& Ojala 2016, 58). Mikäli näin on, työn prekaari tilanne ikään kuin normalisoituu ja palaa ennalleen markkinatilanteen parannuttua. Näin voi joidenkin ammattien ja työtehtävien kohdalla tapahtuakin, mutta on vaikea nähdä kahtia jakautuneiden työmarkkinoiden yhdistyvän ja palaavan ennalleen taloudellisen tilanteen kohennuttua (Soininen 2015).

Haastattelussaan harrastustoiminnan ohjaaja kertoo, että hänet on valittu sijaiseksi julkisen sektorin asiantuntijatehtävään. Vuoden kestävä sijaisuus muuttaa jälleen hänen työtilannettaan keskeisellä tavalla. Hän ei kuitenkaan aio luopua kokonaan harrastustoiminnan ohjaamisesta, sillä hän katsoo, että hänen on myös jatkossa pidettävä yllä toisen ammatin ammattitaitoa ja yhteistyösuhteita.

"Yritän nyt sen verran jatkaa näitä ohjaustöitä, että pidän työsuhteeni jotenkin edes nimellisesti yllä, koska olen tässä ennenkin nähnyt miten nopeasti nää työtilanteet voi muuttua. En halua tästä mun kakkosammatin tuomasta turvaverkosta kokonaan 
luopua, mutta pyrin järjestämään niin, että se olis esimerkiks työpäivää ennen aamulla ja tai sitten viikonloppuna."

Epävarmoilla työmarkkinoilla toinen ammatti, joka ei ole erityisen altis taloussuhdanteille tai muille epävarmuuksille, tuo turvaa ja tunteen jatkuvuudesta. Näin siitä huolimatta, ettei tällaista tuntiperustaista työtä voi pitää erityisen varmana. Silti se tarjoaa jotain enemmän kuin mahdollisuus työttömäksi jäämisestä sijaisuuden päätyttyä. Se tarjoaa jonkinlaisen, joskin heikon lupauksen paikasta työmarkkinoilla.

\section{HAURASTUVAN TYÖN RAJATTOMUUS}

Harrastustoiminnan ohjaaja on esimerkki siitä, miten näennäisen vakaasta asiantuntijatyöstä voi ennakoimattomasti tipahtaa prekaariin työmarkkina-asemaan. Vaikka haastatteluaineiston muut asiantuntijat näyttävät työskentelevän suhteellisen vakaissa asemissa, todennäköisesti sama ennakoimaton työtilanteen muutos voisi tapahtua heistä miltei kenelle vaan. Siinä mielessä harrastustoiminnan ohjaaja ei ole erityinen poikkeus tai erikoisuus asiantuntijatehtävissä työskentelevien naisten keskuudessa.

Harrastustoiminnan ohjaaja on myös esimerkki, joka kuvaa monella tavalla uuden työn etuja ja haittoja. Myönteiseksi puoleksi voi laskea uudenlaisen, suhteellisen vapaan ja itse päätettävissä olevan työn tekemisen tavan. Työt voi - toki tiettyyn rajaan saakka - järjestää oman aikataulun, perheen ja muun elämän asettamiin raameihin. Sama vapaus koskee työn määrää ja tekemisen aikaa sekä paikkoja ylipäätään. Tällainen valinnan vapaus muistuttaa yrittäjän vapautta oman työnsä suhteen. Vapauden voi tulkita myös toisin. Sen voi nähdä jatkuvana pinnistelynä työn saamiseksi ja aikataulujen järjestämiseksi.

Valinnan vapauden myötä raja työn ja ei-työn välillä hämärtyy, ja työntekijän on käytettävä yhä enemmän aikaa sellaisen työn tekemiseen, jonka tavoitteena on työn saaminen tai säilyttäminen. Samalla käy entistä epäselvemmäksi, mikä on työn ulkopuolelle sijoittuvaa elämää ja arkea. Jos aiemmassa tuotannon mallissa työ oli selkeästi erillään perheestä, ja arki sijoitettiin perheen piiriin, sekoittuu tällainen dikotominen jaottelu lopullisesti uuden työn myötä. (Jokinen 2013, 12.)

Kysymys ei ole vain työn ja ei-työn ajallisesta sekoittumisesta, vaan myös niiden tekemisen paikat eivät ole enää selkeästi erillään toisistaan, ja sijoittuneina tiettyihin, fyysisiin ympäristöihin. Työ, ja toisaalta myös koti ja perhe sekä opiskelu kulkevat mukana minne vaan. Ne jaksottuvat eri mittaisiin pätkiin, kotona tehtävään ei-kotityöhön, opiskeluun autossa parkkipaikalla ja kotiasioiden miettimiseen sekä organisointiin työn lomassa. Harrastustoiminnan ohjaajan kuvaama elämän sfäärien sekoittuminen ja siitä seuraava työn, perheen ja opiskelun ajattomuus sekä paikattomuus on hyvä esimerkki siitä työn ja samalla koko elämän laadullisesta muutoksesta, jota työn feminisoitumisen käsitteen avulla on pyritty kuvaamaan.

Myös koulutus ja opiskeleminen korostuvat uudella tavalla, kun niiden avulla pyritään vähentämään tai kompensoimaan työn ennakoimattomuutta. Suomalaisessa yhteiskunnassa usko siihen, että koulutus lisää mahdollisuuksia työmarkkinoilla, on säilynyt suhteellisen vahvana.

Uusi työ ei automaattisesti ja väistämättä tarkoita kaiken työn haurastumista, ja muuttumista prekaariksi. Suuri osa uuden työn tekijöistä viihtyy ja menestyy työssään ilman kokemusta työn haurastumisesta, vaikka uusi työ olisi muuttanut myös heidän työn tekemisen tapaa oleellisesti. Joillekin, kuten harrastustoiminnan ohjaajalle, uusi työ merkitsee oman työmarkkina-aseman heikentymistä ja työn haurastumista. Nämä molemmat uuden työn puolet ovat olemassa samaan aikaan, eivätkä ne sulje toisiaan pois. Oleellista olisi kuitenkin selvittää, kenen työ haurastuu ja kuka menestyy uuden työn markkinoilla.

\section{Tutkimusta on rahoittanut Suomen Akatemia} (Flexlife-projekti, nro. 2777376).

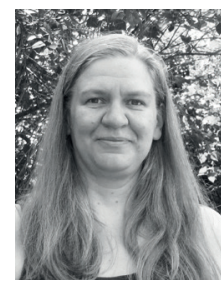

Tuija Koivunen

YTT, tutkija

Yhteiskunta- ja kulttuuritieteiden yksikkö

Tampereen yliopisto 
Adkins, L. (2012). Out of work or out of time? Rethinking Labor after the financial crisis. The South Atlantic Quarterly 111:4, 621-641.

Adkins, L. (2008). From retroactivation to futurity: The end of the sexual contract? NORA - Nordic Journal of Feminist and Gender Research 16(3), 182-201.

Adkins, L. \& Jokinen, E. (2008). Introduction: Gender, living and labour in the fourth shift. NORA - Nordic Journal of Feminist and Gender Research 16(3), 138-149.

du Gay, P. \& Morgan, G. (2013). Understanding capitalism: Crises, legitimacy, and change through the prism of the new spirit of capitalism. Teoksessa du Gay, Paul \& Morgan, Glenn: New spirits of capitalism? Crisis, justifications, and dynamics. Oxford: Oxford University Press, 1-42.

Ikonen, H.-M. (2010). Muutu ihmiseksi, joka olet. Maalla-lehti jälkimodernin työntekijän ja paikan kuvaajana. Alue ja Ympäristö 39(2), 39-52.

Jokinen, E. (2013). Prekaari sukupuoli. NaistutkimusKvinnoforskning 26(1), 5-18.

Jokinen, E. (2005). Aikuisten arki. Helsinki: Gaudeamus.

Julkunen, R. (2008). Uuden työn paradoksit. Keskusteluja 2000-luvun työprosess(e)ista. Tampere: Vastapaino.

Kasvio, A. (2014). Kestävä työ ja hyvä elämä. Helsinki: Gaudeamus.

Koivunen, T. (2013). Miesjohtajien yhteisyys uuden talouden yrityksessä. Naistutkimus-Kvinnoforskning 26(2), 17-28.

Koivunen, T. \& Ojala, H. (2015). Joogaopettajat. Sukupuolistunutta työtä talouden laitamilla. Sukupuolentutkimus-Genusforskning 28(2), 5-18.

Krippendorff, K. (2004). Content analysis. An introduction to its methodology. Thousand Oaks: Sage.

Lahelma, E. (2014). Troubling discourses on gender and education. Educational Research 56(2), 171-183.

Morini, C. (2007). The Feminization of Labor in Cognitive Capitalism. Feminist Review 87(1), 40-59.

Pyöriä, P (2006). Understanding work in the age of information. Finland in focus. Acta Universitatis Tamperensis 1143. Tampere: Tampere University Press.
Pyöriä, P. \& Ojala, S. (2016). Prekaarin palkkatyön yleisyys: liioitellaanko työelämän epävarmuutta? Sosiologia 53(1), 45-63.

Pärnänen, A. \& Sutela, H. (2014). Itsensätyöllistäjät Suomessa 2013. Helsinki: Tilastokeskus.

Saari, T. (2014). Psykologiset sopimukset ja organisaatioon sitoutuminen tietotyössä. Acta Universitatis Tamerensis 1944. Tampere: Tampere University Press.

Silvasti, T. \& Lempiäinen, K. \& Kankainen, T. (2014). Eriarvoisuuden uudet paikat. Teoksessa Kirsti Lempiäinen \& Tiina Silvasti (toim.) Eriarvoisuuden rakenteet. Haurastuvat työmarkkinat Suomessa. Tampere: Vastapaino.

Silvennoinen, H. \& Klas, K. (1996). Kestääkö koulutususko työttömyyden? Kasvatus 27(1), 62-71.

Soininen, T. (2015). Changing expectations and realities of employment stability. Longitudinal analysis on tenures in Finland. Dissertations in Social Sciences and Business Studies 102. Joensuu: Itä-Suomen yliopisto.

Suoranta, A. \& Anttila, A.-H. (toim.) (2010). Yksin sovittu. Osapuolet, luottamus ja työmarkkinalogiikka. Vastapaino: Tampere.

Thrift, N. (2005). Knowing capitalism. Los Angeles: Sage.

Thrift, N. (2000). Performing Cultures in the New Economy. Annals of the Association of American Geography 90(4), 674-692.

Tuomi, J. \& Sarajärvi, A. (2009). Laadullinen tutkimus ja sisällönanalyysi. 5. uudistettu laitos. Helsinki: Tammi.

Vuorinen-Lampila, P. (2016). Gender segregation in the employment of higher education graduates. Journal of Education and Work 29(3), 284-308.

Vähämäki, J. (2011). Tehdasasetusten palauttaminen. Teoksessa Eeva Jokinen, Jukka Könönen, Juhana Venäläinen \& Jussi Vähämäki (toim.) "Yrittäkää edes!" Prekarisaatio Pohjois-Karjalassa. Helsinki: Tutkijaliitto, 163-189.

Åkerblad, L. (2014). Epävarmuuden tuolla puolen. Muuttuvat työmarkkinat ja prekaari toimijuus. Dissertations in Social Sciences and Business Studies 73. Joensuu: Itä-Suomen yliopisto. 